\title{
Analysis of Critical Thinking Skills in Junior High School Students
}

\author{
Dessy Laila Kamsinah ${ }^{1 *}$, Abdullah $^{2}$, Suryajaya ${ }^{3}$
}

${ }^{1}$ Masters Program of Natural Sciences Teaching, Lambung Mangkurat University, Banjarmasin, Indonesia

${ }^{2}$ Department of Chemistry, Faculty of Mathematics and Natural Science, Lambung Mangkurat University, Indonesia

${ }^{3}$ Department of Physics, Faculty of Mathematics and Natural Science, Lambung Mangkurat University, Indonesia

\begin{abstract}
DOI: $10.36348 /$ jaep.2020.v04i06.002
| Received: 30.05 .2020 | Accepted: 08.06.2020 | Published: 12.06 .2020

*Corresponding author: Dessy Laila Kamsinah
\end{abstract}

\section{Abstract}

The increasingly complex development era provides demands to the world of education in order to produce competent Human Resources in various competencies, especially the potential for critical thinking. The $21^{\text {st }}$ century education process is not just an educational process to make children know and understand a certain amount of knowledge. $21^{\text {st }}$ century learning includes critical thinking skills, creative thinking skills, communication and collaboration. Critical thinking skills are high level thinking skills logically and critically using deep reasoning to consider emerging ideas. The method used in this research is descriptive research method. The level of mastery of students' critical thinking skills is obtained by dividing the scores obtained by students with a maximum score multiplied by one hundred percent. Based on the results of data analysis and discussion it can be concluded that the critical thinking skills of SMPN 1 Piani students are still relatively low.

Keywords: Analysis, critical thinking, descriptive research.

Copyright @ 2020: This is an open-access article distributed under the terms of the Creative Commons Attribution license which permits unrestricted use, distribution, and reproduction in any medium for non-commercial use (NonCommercial, or CC-BY-NC) provided the original author and sources are credited.

\section{INTRODUCTION}

The increasingly complex development era provides demands to the world of education in order to produce competent Human Resources in various competencies, especially the potential for critical thinking [1]. The $21^{\text {st }}$ century education process is not just an educational process to make children know and understand a certain amount of knowledge. $21^{\text {st }}$ century learning includes critical thinking skills, creative thinking skills, communication and collaboration. Thus critical thinking skills are one of the important skills for students to have in order to face $21^{\text {st }}$ century competition [2,3]. The implementation of the 2013 curriculum is a form of government effort to train students' thinking skills. This means that teachers must be able to present a model / method of learning that can stimulate students to have good critical thinking skills, not just to know and understand the material delivered by the teacher. Students who can think well and wisely in making a decision in the problem, will get success in life.

Critical thinking skills are high level thinking skills logically and critically using deep reasoning to consider emerging ideas $[4,5]$. In addition, Fachrurazi [6] defines critical thinking as a systematic process that gives students the opportunity to formulate and evaluate their own beliefs and opinions. In addition, Facione [7] suggested that critical thinking skills are a process of thinking that is directed, precise, and trusted in making decisions. Based on some experts opinions, it can be concluded that critical thinking skills are one's skills in making a trusted decision by using deep reasoning to consider the ideas that arise. Critical thinking skills are one of the skills needed in everyday life to solve problems because critical thinking skills involve the ability to reason, interpret, and be able to evaluate information to make the best and valid decisions.

Competence in critical thinking as measured by Watson-Glaser, is defined as the ability represented by the five domain tests as follows.

a. Conclusion. Distinguish between the degree of truth or error of conclusions drawn from the data provided.

b. Recognition of Assumptions. Be aware of unwritten assumptions or assumptions in the statement or statement given.

c. Deduction. Determine whether certain conclusions should follow from information in certain reports or places.

d. Interpretation. Weigh the evidence and decide whether generalizations or conclusions based on the data provided are guaranteed. 
e. Evaluation of Arguments. Distinguish between strong and relevant arguments and those who are weak or irrelevant to a particular issue.

In addition, Facione [7] explains that the skills possessed by someone who thinks critically consists of three main steps as follows:

The first steps in the thought process include:

a. Interpretation (interpretation)

Interpretation is the stage where students understand and correct meaning.

b. Analysis (analysis)

Analysis is the stage where students identify the relationships between statements.

c. Evaluation

Evaluation is the stage where students assess the strength of existing statements.

The second step is to be a thinker:

d. Conclude (Inference)

Concluding is the stage where students obtain information and make conclusions from the source of that information.

e. Explanation (explanation)

Explanation is the stage where students are able to state the results of reasoning.

The third step results from the process of thinking and becoming a thinker namely:

f. Self Regulation (self regulation)

Self-regulation as a stage of networking the results of the process of thinking and becoming a thinker.
Indicators of critical thinking skills emphasized in this study are interpretation, analysis, evaluation, inference, explanation, and self regulation.

\section{RESEARCH METHODS}

The method used in this research is descriptive research method. Descriptive research method aims to determine the initial critical thinking skills of junior high school students. Data was collected by dividing the question sheets consisting of 5 questions about the topic of temperature and heat in the form of essay questions to all $7^{\text {th }}$ grade students of SMPN 1 Piani. The question used is a matter of valid knowledge. The analysis used is quantitative descriptive analysis. The level of mastery of students' critical thinking skills is obtained by dividing the scores obtained by students with a maximum score multiplied by one hundred percent. If written systematically as follows [8].

$$
N P=\frac{R}{S M} X 100 \%
$$

Information:

NP: percentage value sought

$\mathrm{R}$ : scores obtained by students

SM: maximum score

Mastery of students' critical thinking skills is divided into five categories: very low, low, medium, high, and very high. Categories are used to interpret the data obtained using the criteria table [9].

Table-1: Categories of critical thinking skills

\begin{tabular}{|l|l|l|}
\hline No & Category & Percentage score $(\boldsymbol{\%})$ \\
\hline 1 & Very low & $\mathrm{X} \leq 24.95$ \\
\hline 2 & Low & $24.95<\mathrm{X} \leq 41.65$ \\
\hline 3 & Intermediate & $41.65<\mathrm{X} \leq 58.35$ \\
\hline 4 & High & $58.35<\mathrm{X} \leq 75.05$ \\
\hline 5 & Very high & $75.05<\mathrm{X}$ \\
\hline
\end{tabular}

The study population was students of SMPN 1 Piani, the study sample was $7^{\text {th }}$ grade students at SMPN 1 Piani, amounting to 39 people consisting of 22 female and 17 male.

\section{RESEARCH RESULTS AND DISCUSSION}

The study began with a visit to SMPN 1 Piani, the researchers observed the learning process and conducted interviews with science subject teachers. The results of the visit showed that the learning process that took place at school did not involve students actively in the learning process, the students looked passive. The tools used by teachers also still cannot facilitate students' critical thinking skills.

The study was conducted by giving 5 questions about the topic of temperature and heat which can measure 5 critical thinking skills of students who are already valid. Based on the analysis of students' answers obtained critical thinking skills of students at SMP Negeri 1 Piani each indicator is presented in the following figure: 


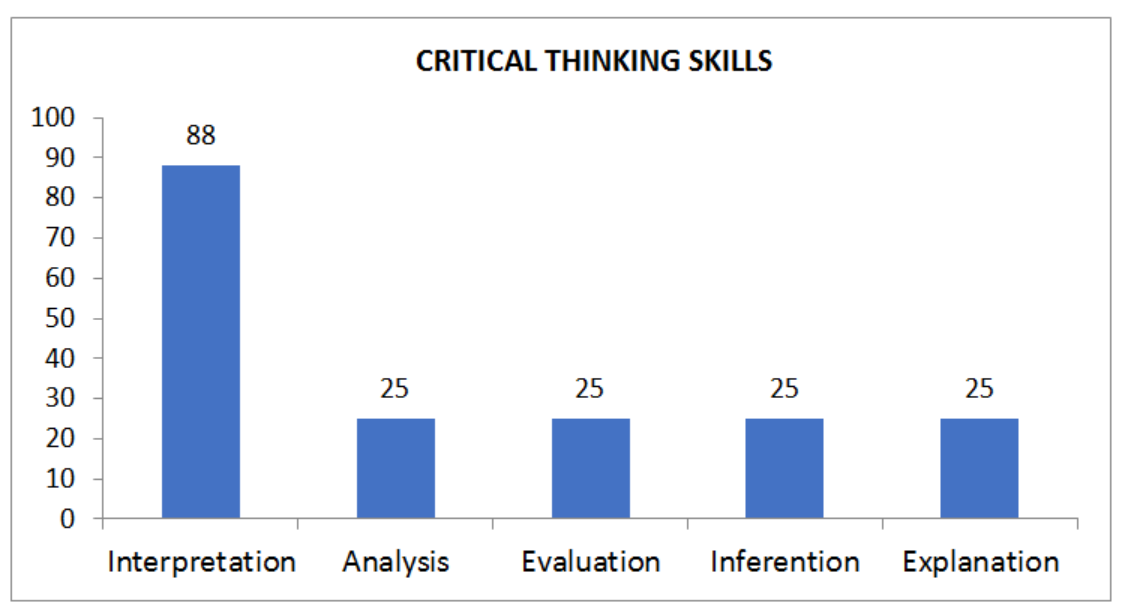

Fig-1: Percentage of critical thinking skills of students of SMP Negeri 1 Piani

The results of the study were analyzed based on indicators of critical thinking skills contained in the instruments being tested namely indicators of interpretation, analysis, evaluation, inference, and explanation. Based on the results of data analysis Figure-1 that has been obtained from 5 indicators of critical thinking skills of students who get the highest percentage is the aspect of interpretation by $88 \%$ with a very high category. While the other 4 indicators namely indicators of analyzing, evaluating, inferencing and explaining have the same percentage of $25 \%$ with a low category.

Most of the students were able to answer question number 1 , students were able to interpret the phenomenon but there were still some students who answered incompletely and incorrectly categorized the desired phenomenon in the problem. Whereas in questions number 2, 3, 4, and 5 most students were unable to answer questions correctly, the inability of students to answer questions number $2,3,4$, and 5 showed the weakness of students' critical thinking skills on indicators of analysis, evaluation, inference and explanation. Weak learners in analyzing because students are not used to identifying the relationship of various statements, concepts, data and others. Likewise with the weakness of students' critical thinking skills on the evaluation indicators caused students are less able to judge the truth of a statement. Students are also still weak in indicators of inference and explanation, this is because students have not been able to identify the elements needed to settle conclusions and provide evidence of the truth of a statement or reasoning. Based on the results of an interview with one of the students and natural science teacher said that students are not accustomed to the type of questions such as numbers 2 , 3,4 , and 5 so that it feels very difficult. Likewise with the statement from the subject teacher who said that he never gave questions that were able to train students' thinking skills. This has an impact on the lack of trained students' critical thinking skills.
The low critical thinking skills of students are in line with research conducted by Prihartiningsih et al., [10]; Martawijaya [11] and Normaya [12] which state that critical thinking skills of junior high school students are still in the low category. The low critical thinking skills of junior high school students is one of them caused by the learning process that is still dominated by teachers. This is as revealed by Patonah [13] in her research which said that the learning process in Indonesia still tends to be dominated by teachers and memorized. The low critical thinking skills of students will certainly have a negative impact on the next learning process. Critical thinking skills of students that are still low indicate that the need for improvement of the learning process in the classroom, because basically critical thinking skills can be trained in a learning process as conveyed by Yuliati [14]. There are several ways that can be done to practice critical thinking skills, namely reading critically, increasing the power of analysis of a problem and providing solutions with good and bad considerations; c) develop the ability to observe; d) increase curiosity by asking quality questions that is questions that do not directly have a right or wrong answer or not just one right answer so that it demands students to think hard. Critical thinking skills can also be trained with learning processes that are oriented towards students so that they are more active [15-17]. Creative problem solving is one of the learning models that can train students' critical thinking skills as research conducted by Nursiami \& Soeprodjo [18]; Puspitasari [19]; Indayatmi [20]; and Subakir [21].

\section{CONCLUSION}

Based on the results of data analysis and discussion it can be concluded that the critical thinking skills of SMPN 1 Piani students are still relatively low. So it takes some effort or improvement steps in education to improve students' critical thinking skills.

\section{REFERENCES}

1. Majid, A., \& Rochman, C. (2014). Pendekatan Ilmiah Dalam Implementasi Kurikulum 2013. Bandung: Rosda. 
Dessy Laila Kamsinah et al; J Adv Educ Philos, June, 2020; 4(6): 234-237

2. Abidin, Y. (2015). Pembelajaran multiliterasi (sebuah jawaban atas tantangan pendidikan abad 21). Bandung: Refika aditama.

3. Zaini, M. (2016). Urgensi Penelitian Pengembangan Dalam Menggali Keterampilan Berpikir Kritis. Prosiding Seminar Nasional Pendidikan Ipa Mengembangkan Keterampilan Berpikir Tingkat Tinggi Melalui Pembelajarn Ipa. S2 Ipa Unlam Banjarmasin Press.

4. Fahim, M., \& Pezeskhi, M. (2012). Manipulating Critical Thinking Skills in Test Taking. International journal of education ISSN 19485476, 2012, 4(1).

5. Smith, G. M. (2003). Film structure and the emotion system. Cambridge University Press.

6. Fachrurazi, T. P. (2011). Penerapan Pembelajaran Berbasis Masalah untuk Meningkatkan Kemampuan Berpikir Kritis dan Komunikasi Matematika Siswa SD.S3 Pendidikan Matematika, Program Pascasarjana, Universitas Pendidikan Indonesia, Indonesia.

7. Facione, P. A. (2011). Critical thinking: What is it and why it counts. Millbrae. Measured Reasons and the California Academic Press.

8. Purwanto, N. (2004). Prinsip-prinsip dan teknik evaluasi pengajaran. Bandung: PT. Remaja Rosdakarya.

9. Azwar, S. (2014). Penyusunan skala psikologi Edisi 2. Yogyakarta: Pustaka Pelajar.

10. Prihartiningsih., Zubaidah, S., \& Kusairi. (2016). Kemampuan Berpikir Kritis Siswa SMP pada Materi Klasifikasi Makhluk Hidup. Prosiding Seminar Nasional Pendidikan IPA Pascasarjana UM, (1)1053-1062.

11. Martawijaya, M. A. (2015). Buku fisika peserta didik berbasis kearifan lokal untuk meningkatkan karakter dan ketuntasan belajar. Jurnal Sains dan Pendidikan Fisika, 10(3).

12. Normaya, K. (2015). Kemampuan Berpikir Kritis dalam Pembelajaran Matematika dengan Menggunakan Model JUCAMA di Sekolah Menengah Pertama. Edu-Mat Jurnal Pendidikan Matematika. 3(1), 92-104. Retrieved from http://ppjp.unlam.ac.id/journal/index.php/edumat/a rticle/view/634/542.

13. Patonah, S. (2014). Elemen Bernalar Tujuan pada Pembelajaran IPA Melalui pendekatan Metakognitif Siswa SMP. Jurnal Pendidikan IPA
Indonesia, 3(2), 128-133. DOI: http://dx.doi.org/10.15294/jpii.v3i2.3111.

14. Yuliati, L. (2013). Efektivitas Bahan Ajar IPA Terpadu terhadap Kemampuan Berpikir Tingkat Tinggi Siswa SMP. Jurnal Pendidikan Fisika Indonesia, 9(1), 55-57. DOI: http://dx.doi.org/10.15294/jpfi.v9i1.2580.

15. Azizmalayeri, K., Misrshjafari, E., Sharif, M., Asgari, M., \& Omidi, M. (2012). The Impact of Guided Inquiry Methods of Teaching on The Critical Thinking of High School Students. Journal of Education and Practice, 3(10), 42-48. Retrieved from http://www.iiste.org/Journals/index.php/JEP/articl e/view/2530.

16. Fuad, A. F. M., Mahmood, I. A., Ahmad, S., Norsahperi, N. M. H., Toha, S. F., Akmeliawati, R., \& Darsivan, F. J. (2017, March). Modeling and simulation for heavy-duty mecanum wheel platform using model predictive control. In IOP Conference Series: Materials Science and Engineering (Vol. 184, No. 1, p. 012050). IOP Publishing.

17. Jack, G. U. (2013). Concept Mapping and Guided Inquiry as Effective Techniques for Teaching Difficult Concepts in Chemistry: Effect on Students' Academic Achievement. Journal of Educational and Practice, 4(5):9-16. Retrieved from

http://www.iiste.org/Journals/index.php/JEP/articl e/view/4782.

18. Nursiami, S., \& Soeprodjo. (2015). Keefektifan Model Pembelajaran Creative Problem Solving Berbantuan Flash Interaktif terhadap Hasil Belajar. Jurnal Inovasi Pendidikan Kimia. 9(1):1440-1449.

19. Puspitasari, N. W. (2018). Penerapan Pendekatan Creative Problem Solving (CPS) pada Konsep "Gaya” untuk Meningkatkan Hasil Belajar Siswa. Jurnal Pendidikan. 19(1):53-67.

20. Indayatmi. (2017). Peningkatan Hasil Belajar Analisis itrimetri Melalui Model Creative Problem Solving pada Peserta Didik SMK. Jurnal Pendidikan Sains. 5(2):88-99.

21. Subakir, M. (2013). Peningkatan Berpikir Kreatif dan Hasil Belajar Fisika Melalui Pendekatan Creative Problem Solving (CPS). Jurnal Pendidikan. 2(2). 